\title{
Dopamine D3 receptor dysfunction prevents anti-nociceptive effects of morphine in the spinal cord
}

\author{
Kori L. Brewer ${ }^{\text {*t}}$, Christine A. Baran ${ }^{1}$, Brian R. Whitfield ${ }^{1}$, A. Marley Jensen ${ }^{2}$ and Stefan Clemens ${ }^{2+}$ \\ ${ }^{1}$ Department of Emergency Medicine, Brody School of Medicine, East Carolina University, Greenville, NC, USA \\ ${ }^{2}$ Department of Physiology, Brody School of Medicine, East Carolina University, Greenville, NC, USA
}

\author{
Edited by: \\ Brian R. Noga, University of Miami, \\ USA \\ Reviewed by: \\ Deborah Baro, Georgia State \\ University, USA \\ Florian Klinker, University Medical \\ Centre, Göttingen, Germany \\ *Correspondence: \\ Kori L. Brewer, Department of \\ Emergency Medicine, Brody School \\ of Medicine, East Carolina \\ University, 600 Moye Blvd., Mail \\ Stop \#625, Greenville, NC 27834, \\ USA \\ e-mail: brewerk@ecu.edu \\ ${ }^{\dagger}$ Co-senior authors.
}

Dopamine (DA) modulates spinal reflexes, including nociceptive reflexes, in part via the D3 receptor subtype. We have previously shown that mice lacking the functional D3 receptor (D3KO) exhibit decreased paw withdrawal latencies from painful thermal stimuli. Altering the DA system in the CNS, including D1 and D3 receptor systems, reduces the ability of opioids to provide analgesia. Here, we tested if the increased pain sensitivity in D3KO might result from a modified $\mu$-opioid receptor (MOR) function at the spinal cord level. As D1 and D3 receptor subtypes have competing cellular effects and can form heterodimers, we tested if the changes in MOR function may be mediated in D3KO through the functionally intact D1 receptor system. We assessed thermal paw withdrawal latencies in D3KO and wild type (WT) mice before and after systemic treatment with morphine, determined MOR and phosphorylated MOR ( $\mathrm{p}-\mathrm{MOR}$ ) protein expression levels in lumbar spinal cords, and tested the functional effects of DA and MOR receptor agonists in the isolated spinal cord. In vivo, a single morphine administration $(2 \mathrm{mg} / \mathrm{kg})$ increased withdrawal latencies in WT but not D3KO, and these differential effects were mimicked in vitro, where morphine modulated spinal reflex amplitudes (SRAs) in WT but not D3KO. Total MOR protein expression levels were similar between WT and D3KO, but the ratio of pMOR/total MOR was higher in D3KO. Blocking D3 receptors in the isolated WT cord precluded morphine's inhibitory effects observed under control conditions. Lastly, we observed an increase in D1 receptor protein expression in the lumbar spinal cord of D3KO. Our data suggest that the D3 receptor modulates the MOR system in the spinal cord, and that a dysfunction of the D3 receptor can induce a morphine-resistant state. We propose that the D3KO mouse may serve as a model to study the onset of morphine resistance at the spinal cord level, the primary processing site of the nociceptive pathway.

Keywords: dopamine d3 receptor, mu-opiod receptor, nociception, second messenger cross-talk, dopamine d1 recptor, spinal reflexes

\section{INTRODUCTION}

Opiate analgesics are the classical first line treatment for strong and persistent pain, but their effectiveness in long-term treatment is limited by the emergence of tolerance (Colpaert, 2002; Dupen et al., 2007; Bekhit, 2010; Joseph et al., 2010). This morphineresistant condition is thought to arise over time and involve a dysfunction of $\mu$-opioid receptor (MOR)- and dopamine (DA)receptor mediated cAMP/PKA second messenger pathways in the brain (Suzuki et al., 2001; Schmidt et al., 2002; Fazli-Tabaei et al., 2006; Zhang et al., 2008, 2012; Le Marec et al., 2011; Enoksson et al., 2012). However, under this tenet the role of the spinal cord remains overlooked. The spinal cord is the first site for the processing for nociceptive information, and it houses both DA and MOR receptors in the dorsal horn (Abbadie et al., 2001; Levant and McCarson, 2001; Ray and Wadhwa, 2004; Zhu et al., 2007, 2008). DA regulates spinal cord circuits, including painassociated responses (Garraway and Hochman, 2001; Clemens and Hochman, 2004; Yang et al., 2005; Keeler et al., 2012), and both D1 and D3 receptors are present in the dorsal horn (Levant and McCarson, 2001; Zhu et al., 2007). Further, the MOR is associated with inhibitory $G$ proteins $\left(G_{i}\right.$ and $\left.G_{o}\right)$ and is present in the spinal cord (Mansour et al., 1994; Ji et al., 1995; Ray and Wadhwa, 1999, 2004; Abbadie et al., 2001, 2002; Zhang et al., 2006). Upon ligand binding to the receptor, signaling cascades are activated that inhibit cAMP production, resulting in the opening of $\mathrm{K}^{+}$ channels or closing of $\mathrm{Ca}^{2+}$ channels (Connor and Christie, 1999; Connor et al., 1999; Williams et al., 2001). Its desensitization is under the control of G-protein-coupled receptor kinase (GRK)mediated phosphorylation (Connor et al., 2004; Gainetdinov et al., 2004; Garzon et al., 2005), followed by B-arrestin-mediated internalization (Bohn et al., 1999, 2000; Ohsawa et al., 2003; Connor et al., 2004). Blocking B-arrestin expression improves morphine-mediated analgesia (Li et al., 2009), and recent data suggest that morphine-induced $B$-arrestin complex formation primarily requires D1 receptors (Urs et al., 2011).

Interestingly, D1 receptors form heterodimers with D3 receptors (Surmeier et al., 1996; Fiorentini et al., 2008; Maggio et al., 2009; Missale et al., 2010; Cruz-Trujillo et al., 2013) and both 
play a role in opioid tolerance (Lin et al., 1996; Cook et al., 2000; Richtand et al., 2000; Fazli-Tabaei et al., 2006). We recently found that animals lacking a functional D3 receptor (D3KO) exhibited facilitated pain-associated reflexes (Keeler et al., 2012), and we address here the role of the spinal D3 receptor on MOR functional states and morphine responsiveness.

We evaluated thermal pain paw withdrawal latencies in D3KO and wild type (WT) controls before and after administration of morphine, determined naïve MOR and phosphorylated MOR (pMOR) protein expression levels in the lumbar spinal cord, and compared spinal reflex amplitudes (SRA) in isolated spinal cords from WT and D3KO in vitro, to assess the role of the D3 receptor in mediating morphine actions in isolated WT spinal cords.

We found that naïve $\mathrm{D} 3 \mathrm{KO}$ were unresponsive to morphine administration, both in vivo and in vitro, and that this lack of responsiveness was associated with increased levels of spinal pMOR in D3KO. Moreover, while the highly-specific MOR agonist, DAMGO, was able to decrease SRAs in both WT and D3KO in vitro, this effect was significantly smaller in D3KO than WT. Finally, acute pharmacological block of the D3 receptor in the isolated WT cord was sufficient to induce a D3KO-like phenotype and prevent the modulatory actions of morphine on SRAs observed under control conditions.

\section{MATERIALS AND METHODS}

All experimental procedures complied with $\mathrm{NIH}$ guidelines for animal care and were approved by the East Carolina University Institutional Animal Care and Use Committee. Male dopamine D3 receptor knockout mice (D3KO; strain B6.129S4$\operatorname{Drd3}^{\text {tmldac }} / \mathrm{J}$; stock \# 002958, Jackson Laboratory, Bar Harbor, $\mathrm{ME}$ ) and their appropriate associated wild-type (WT) controls (C57BL/6) were used for in vivo behavioral testing and Western blot experiments (3-4 months), while neonatal pups of either sex were used for extracellular electrophysiology and pharmacology (postnatal days 7-14).

\section{BEHAVIORAL ASSESSMENTS}

Thermal withdrawal latencies were tested on $10 \mathrm{D} 3 \mathrm{KO}$ and 8 WT males using a Hargreaves apparatus. Prior to baseline testing, mice were acclimated to the apparatus by being placed in the apparatus for $2 \mathrm{~h}$ per day for a total of 5 days. Baseline thresholds were obtained over three test sessions, with each test session occurring at the same time of day, and each mouse being placed in the chamber to which it was acclimated. Each test session consisted of three trials (i.e., application of the heat stimulus at $56^{\circ} \mathrm{C}$ ) separated by at least $5 \mathrm{~min}$. The latencies obtained over the 3 trials were averaged to get the mean baseline latency for each test day. After baselines were established, a randomly chosen subset of mice (5 D3KO and $4 \mathrm{WT}$ ) was administered morphine sulfate (Sigma, $2 \mathrm{mg} / \mathrm{kg}$, i.p.) and tested $30 \mathrm{~min}$ later as outlined above.

\section{TISSUE COLLECTION AND WESTERN BLOT ANALYSIS}

One week after behavioral testing, animals were deeply anesthetized with inhaled isoflurane (4-5\%), decapitated, and spinal cords were dissected, frozen in liquid nitrogen and stored at $-80^{\circ} \mathrm{C}$. Proteins were homogenized in RIPA buffer containing protease and phosphatase inhibitors (Sigma-Aldrich, St. Lois,
$\mathrm{MO}$ ), lysates centrifuged, and the supernatant collected. Total protein was quantified using an EZQ Quantitation Kit (R33200; Invitrogen, Grand Island, NY). Equal concentrations of protein were separated using a SDS-PAGE (Criterion TGX Any kD, BioRad, Canton, MA) and transferred onto a PVDF membrane (Immobolin-P, Millipore, Germany). To verify consistent protein transfer across the lanes, we measured total protein staining of the membrane with Coomassie Blue, and compared the protein staining with the $\beta$-actin expression in the corresponding lanes. We did not observe any significant difference in $\beta$-actin protein expression between WT and D3KO ( $p=0.54$ and 0.2 , respectively). For MOR and pMOR protein expression assessments, membranes were blocked using 5\% BSA overnight and probed with primary antibodies for the MOR (ab10275, Abcam, UK) at 1:1000 and p-MOR (bs3724R, BIOSS, UK) at 1:1000 overnight. This MOR antibody can detect bands at $\sim 50 \mathrm{kDa}$ (Kerros et al., 2010) and has been verified in a different study by comparing it to the effects of another MOR antibody (Loyd et al., 2008). The pMOR antibody we used shows a strong band at $\sim 44 \mathrm{kDa}$ (http://biossusa. com/store/bs-3724r.html), and control ELISA data provided by BIOSS show an increased binding of this antibody to pMOR over MOR (data not shown, BIOSS, personal communication). Membranes were washed and incubated in anti-mouse and antirabbit secondary antibodies (R\&D Systems, Minneapolis, MN) respectively. Target proteins were visualized using ECL Plus detection reagent (80916; Invitrogen, Grand Island, NY) according to the manufacturer's recommendations, quantified using relative integrated density normalized against $\beta$-actin (ab8226, Abcam, UK) at 1:2000, and analyzed with ImageJ software (version 1.48S, $\mathrm{NIH}$ ). Expression values are given as the ratio of MOR or pMOR to $\beta$-actin.

For D1 receptor protein assessments, membranes were blocked overnight using $5 \% \mathrm{BSA}$ at $4^{\circ} \mathrm{C}$ and probed with primary antibodies for the D1 receptor (ab81296, Abcam, Cambridge, MA) and $\beta$-actin (ab8226, Abcam, UK) at 1:1000 overnight. This D1 receptor antibody can detect bands at both 50 and $75 \mathrm{kDa}$ (Mizuta et al., 2013). Membranes were washed four times at $5 \mathrm{~min}$ in TBS$\mathrm{T}$ and incubated for $30 \mathrm{~min}$ at room temperature using 5\% BSA in anti-rabbit IR800 (35571, Thermo Scientific, Rockford, IL) and anti-mouse IR680 (926-68070, Li-Cor, Lincoln, NE) secondary antibodies at 1:30000. The membranes were then washed another three times for $5 \mathrm{~min}$ in TBS-T followed by two washes at $5 \mathrm{~min}$ in PBS. Target proteins were visualized using the Li-Cor detection system (Odyssey Clx, Li-Cor Biosciences, Lincoln, NE) and associated software (Image Studio, Li-Cor), and quantified with ImageJ. D1 receptor protein expression values were normalized to $\beta$-actin protein expression.

\section{ELECTROPHYSIOLOGY AND PHARMACOLOGY}

A total of 19 WT and 17 D3KO neonatal pups of either sex (postnatal days 7-14) were used for extracellular electrophysiological and pharmacological experiments. As reported earlier (Clemens and Hochman, 2004; Keeler et al., 2012), animals were deeply anesthetized with i.p. injection $(50 \mu \mathrm{l} / 10 \mathrm{~g})$ of a ketamine $(90 \mathrm{mg} / \mathrm{ml}) / x y l a z i n e(10 \mathrm{mg} / \mathrm{ml}) \mathrm{mix}$, and after verification of deep anesthesia decapitated. Spinal cords were removed quickly, usually completed within $10 \mathrm{~min}$, placed in a Sylgard-lined Petri 
dish, the Dura mater desheathed and the cords hemisected. Throughout this process the preparations were submersed in oxygenated $\left(95 \mathrm{O}_{2} / 5 \% \mathrm{CO}_{2}\right)$ ice-cold high-sucrose artificial cerebrospinal fluid (containing in mM: 342 sucrose, 180.2 Glucose, 203.3 $\mathrm{MgCl}_{2}, 147.02 \mathrm{CaCl}_{2}, 137.99 \mathrm{NaH}_{2} \mathrm{PO}_{4}, 84.01 \mathrm{NaHCO}_{3}$, $74.56 \mathrm{KCl}, \mathrm{pH} \mathrm{7.4)}$. After these initial dissection steps, the highsucrose solution replaced with oxygenated artificial cerebrospinal fluid (ACSF; containing in mM: $128 \mathrm{NaCl}, 1.9 \mathrm{KCl}, 10$ Glucose, $1.3 \mathrm{MgSO}_{4}, 2.4 \mathrm{CaCl}_{2}, 1.2 \mathrm{KH}_{2} \mathrm{PO}_{4}, 26 \mathrm{NaHCO}_{3}, \mathrm{pH} 7.4$ ), acclimated to room temperature. Subsequently, small glass suction electrodes were carefully attached to identified dorsal and ventral lumbar roots (usually L2-L5).

After a recovery of phase of $\sim 30-60 \mathrm{~min}$, reflex responses were elicited with a constant current stimulator (Iso-Stim 01D, NPI Electronics, Tamm, Germany, or a custom-built Linear Isolation Unit, Model MI 401, Department of Animal Physiology, University of Cologne) with pulses of $100-500 \mu \mathrm{A}$ for $100-$ $250 \mu \mathrm{s}$. Signals were recorded and amplified with a 4-channel differential AC amplifier (Model 1700, A-M Systems, Sequim, WA), digitized with a Digidata 1440A, and analyzed with pClamp v.10.2 software (Molecular Devices, Sunnyvale, CA). Single pulse stimulations were delivered every $60 \mathrm{~s}$ (WT) or 120-180 s (D3KO) to avoid habituation (data not shown). Reflex responses were recorded and analyzed by rectified integration of the recorded responses. SRAs were obtained before (control conditions) and during application of morphine sulfate (Sigma, $1 \mu \mathrm{M}$ ), the D3 receptor-preferring antagonist, nafadotride (Tocris, $20 \mu \mathrm{M}$ ), or the specific MOR agonist DAMGO (Tocris, $10 \mu \mathrm{M}$ ). For testing the interactions between the D3 and MOR in the WT spinal cord, we first bath-applied the D3-receptor preferring antagonist, nafadotride, to establish the effects of this drug, before adding morphine to the bath. Drugs were bath-applied and for 30-60 min, during which time the stimulus protocol was maintained. Following the drug application testing, drugs were carefully washed out (through ACSF exchange of 4-5 times the bath volume). For analytical purposes, we compared the last 10 consecutive SRAs in the control condition with the last 10 SRAs during the drug application.

\section{STATISTICAL ANALYSIS}

For behavioral experiments, baseline and post-morphine thermal thresholds were compared between WT and D3KO mice using a RM ANOVA (SigmaPlot, Systat, San Jose, CA) with $p<0.05$ indicating significance. For determining differences in MOR and p-MOR protein expression levels between groups, we used using a paired $t$-test (JMP v.10, SAS, Inc., Cary NC) with $p<0.05$ indicating significance. For electrophysiological experiments, SRAs under drug conditions were averaged and normalized to the mean of the pre-drug values, and statistical significance was determined with $t$-tests or ANOVA and subsequent post-hoc comparisons, as appropriate, and with $\alpha$ set $<0.05$ (SigmaPlot, Systat, San Jose, CA).

\section{RESULTS \\ BEHAVIOR}

Under baseline conditions, pain withdrawal latencies of WT were significantly higher than those of D3KO (WT: $6.24 \pm 0.64$, $n=4$; D3KO: $4.84 \pm 1.08 \mathrm{~s}, p<0.001, n=5, t$-test, Figure 1, left panel), suggesting an increased excitability to thermal stimulation of the hindpaw in the D3KO animals. A single injection of morphine $(2 \mathrm{mg} / \mathrm{kg}$, i.p. ) significantly increased thermal withdrawal latencies in WT from $6.24 \pm 0.64 \mathrm{~s}$ to $11.01 \pm 1.91 \mathrm{~s}$ ( $p<0.001$, Figure 1, right panel), whereas they remained unaltered in $\mathrm{D} 3 \mathrm{KO}(4.84 \pm 1.08 \mathrm{~s}$, vs. $3.94 \pm 0.95, p=0.902$, RM-ANOVA). Consequently, the difference in pain withdrawal latencies between morphine-treated WT and D3KO remained significant ( $p<0.001, t$-test). These data suggest that under naïve conditions $\mathrm{D} 3 \mathrm{KO}$ are unresponsive to the system-wide application of morphine.

\section{MOR PROTEIN EXPRESSION IN THE LUMBAR CORD}

To test if changes in MOR levels or phosphorylation status might underlie the lack of the opioid effect observed in $\mathrm{D} 3 \mathrm{KO}$, we assessed MOR and pMOR protein expression levels in lumbar spinal cords of WT and D3KO (Figure 2). We probed lumbar spinal cords of 4 naïve (untreated) WT and $4 \mathrm{D} 3 \mathrm{KO}$ for MOR (Figure 2A) and pMOR protein expression (Figure 2B). In both experiments, we first probed for the respective receptor protein expression before stripping the blot and then probing for $B$-actin. We found that, after normalization to $B$-actin, WT and D3KO had similar levels of total MOR (WT: $1.08 \pm 0.32$ a.u.; D3KO: $1.146 \pm 0.08$ a.u., $p=0.85, n=4$; Figure $2 \mathrm{C}$, left panels). In contrast, pMOR protein expression levels of pMOR in D3KO were significantly elevated over WT (WT: $0.127 \pm 0.03$ a.u., D3KO: $0.992 \pm 0.13$ a.u., $p<0.001$; Figure 2C, $p<0.01$, right panels). As overall MOR but not pMOR expression levels were similar, and both sample groups passed Normality (Shapiro-Wilk; $p=0.441$ and $p=0.509$, respectively) and Equal Variance Tests ( $p=0.085$ and $p=0.505$, respectively), we next calculated the ratio of pMOR to MOR expression levels (Figure 2D). We found that in WT $36.7 \pm 10.6 \%$ of total MOR was phosphorylated,

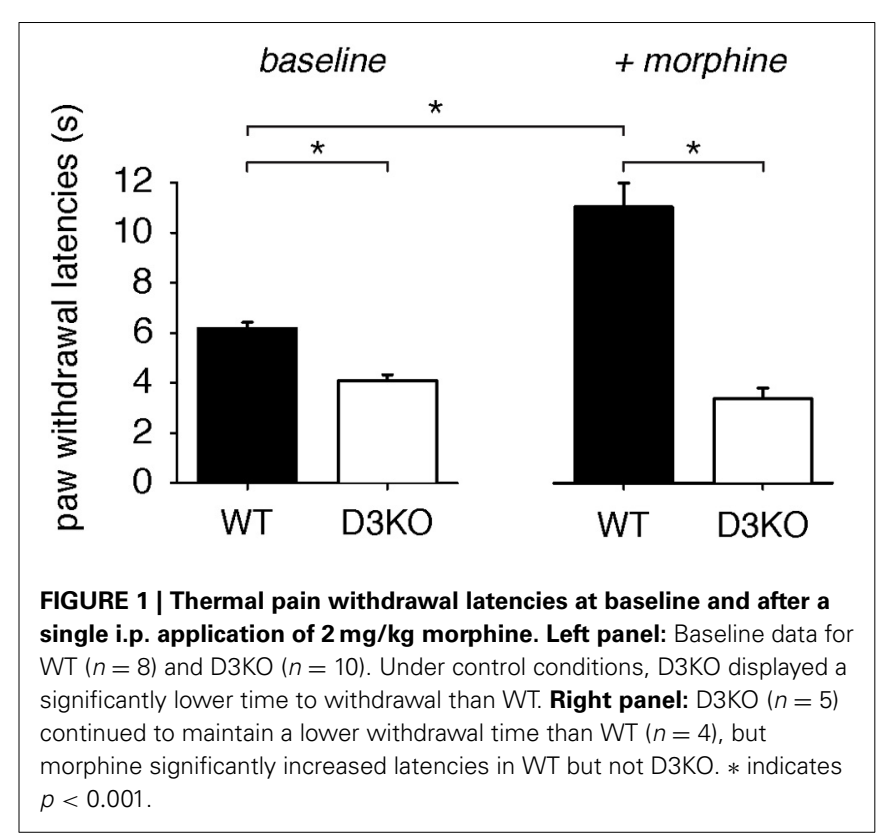




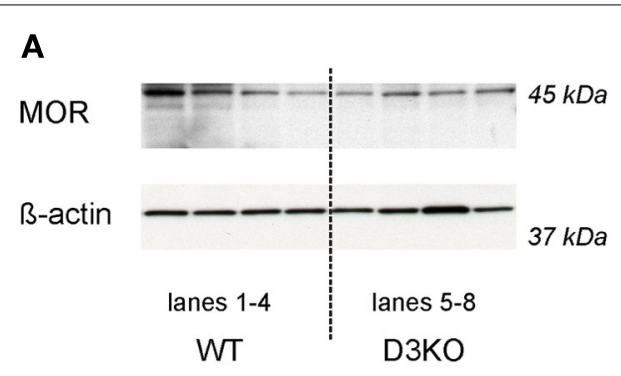

C

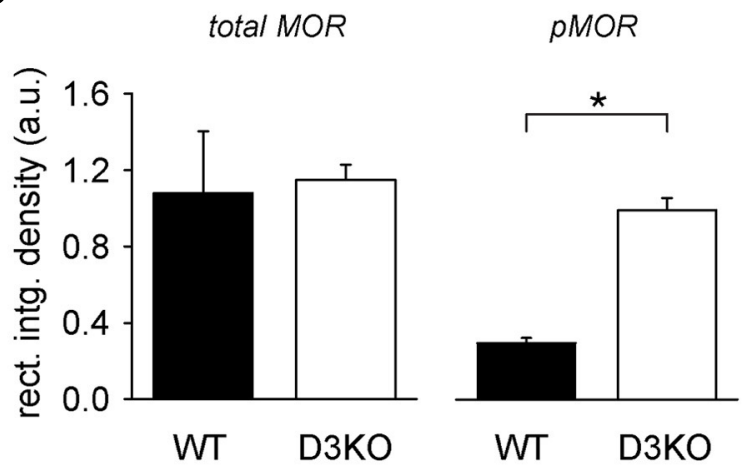

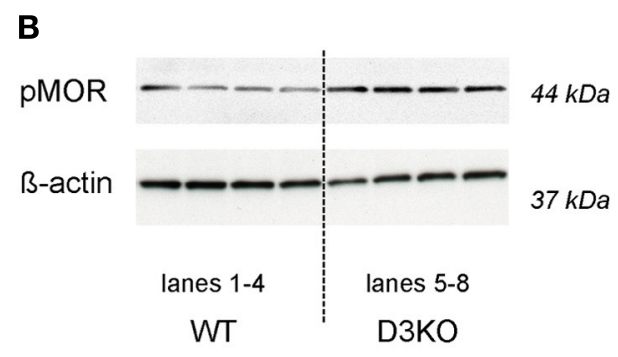

D

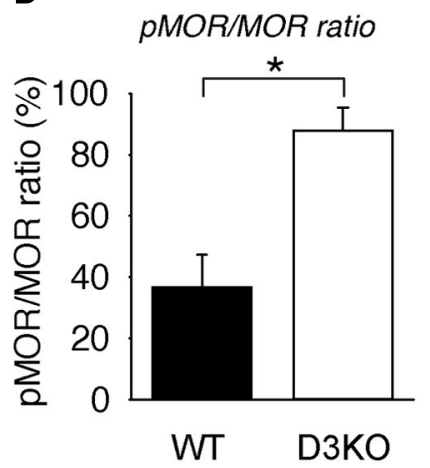

FIGURE 2 | Protein expression levels of total MOR and pMOR in lumbar spinal cord, normalized to $\beta$-actin. (A) Total MOR protein expression in WT and D3KO (top panels), and their respective $ß$-actin protein expressions (bottom panels). Lanes 1-4 represent lumbar spinal cords from four independent WT, while lanes 5-8 represent tissues from four independent D3KO. Total MOR protein expression levels were overall similar between WT and D3KO. Note that we first probed for MOR expression before stripping and re-probing for $ß$-actin. (B) pMOR protein expression levels in WT and D3KO (top lanes), and their respective ß-actin protein expression (bottom panels). Note that pMOR expression levels showed a stronger labeling in D3KO than WT. (C) Quantification of expression data: After normalization of MOR and pMOR data to their respective $\beta$-actin expression in each lane, total MOR protein expression was similar between WT and D3KO $1 * p=0.85$, $n=4$ each). In contrast, pMOR protein expression was significantly increased in D3KO over WT ( $p<0.001, n=4$ each). (D) Ratio of pMOR/MOR protein expression in the lumbar spinal cord of WT and D3KO. In WT, pMOR was low, whereas in D3KO a large majority of MORs was phosphorylated ( ${ }^{*} p=0.008, n=4$ each). while in $\mathrm{D} 3 \mathrm{KO}$ this rate $87.8 \pm 7.6 \%(p=0.008)$, suggesting a reduced availability of the MOR for ligand binding in $\mathrm{D} 3 \mathrm{KO}$.

\section{EXTRACELLULAR ELECTROPHYSIOLOGY AND PHARMACOLOGY}

To test the functional effects of morphine mediated responses at the spinal cord level alone, we next elicited and recorded SRAs in isolated spinal cords of WT and D3KO before and during exogenous application of morphine (Figure 3). Constant-current stimulation of dorsal lumbar roots via glass suction electrodes elicited within a few milliseconds a monosynaptic stretch reflex on the corresponding ventral roots (MSR, Figure 3A1) that generally lasted less than 5-6 ms. The signal traces in the MSR time window were rectified and integrated, and the resulting data points at the end of each sweep were used as a measure of SRA (Figure 3A2).

Bath-application of morphine $(1 \mu \mathrm{M})$ induced in WT a gradual decrease in SRA amplitude (Figure 3B1), and led to a significant reduction in WT SRAs at the end of the recorded application interval, from $100.3 \pm 0.2$ to $75.2 \pm 6.8 \%(p=0.004$, $n=6$, Figure 3B2). In contrast, in $\mathrm{D} 3 \mathrm{KO}$, bath-application of $1 \mu \mathrm{M}$ morphine had no significant modulatory effect on SRA (Figures 3C1,C2; control: $99.8 \pm 0.2 \%$; morphine: $93.2 \pm 4.2 \%$, $p=0.052, n=12$ ). These data mirror the effects observed in the thermal pain paradigm, and they suggest that the behavioral changes observed in the intact animals stem from changes in the D3 receptor system at the spinal cord level.

While preferentially targeting MORs, morphine activates $\partial$ and $\kappa$ receptors as well. To test if a targeted activation of the MOR pathway alone can mimic the effects observed with morphine, we bath-applied the MOR-preferring agonist, DAMGO $(10 \mu \mathrm{M})$, to isolated WT and D3KO spinal cord preparations and assessed its role in modulating SRAs (Figure 4). In WT, DAMGO decreased SRAs from $99.9 \pm 0.1$ to $66.6 \pm 4.5 \%(n=15, p<0.001$, Figure 4A), and it decreased them in D3KO from $100 \pm 0.15$ to $80.9 \pm 3.4 \%(n=8$, Figure 4B). Importantly, the difference in DAMGO-mediated actions between WT and D3KO was significant $(p=0.013)$. These data suggest that in isolated spinal cords of D3KO, MORs are still functionally active and can be recruited by a highly specific agonist, albeit at a smaller magnitude than in WT.

The D3KO animal is a functional, global knockout, and consequently D3 receptor function is compromised in every tissue. To test if D3 receptor dysfunction in the spinal cord is sufficient to mimic the morphine effects observed in the 


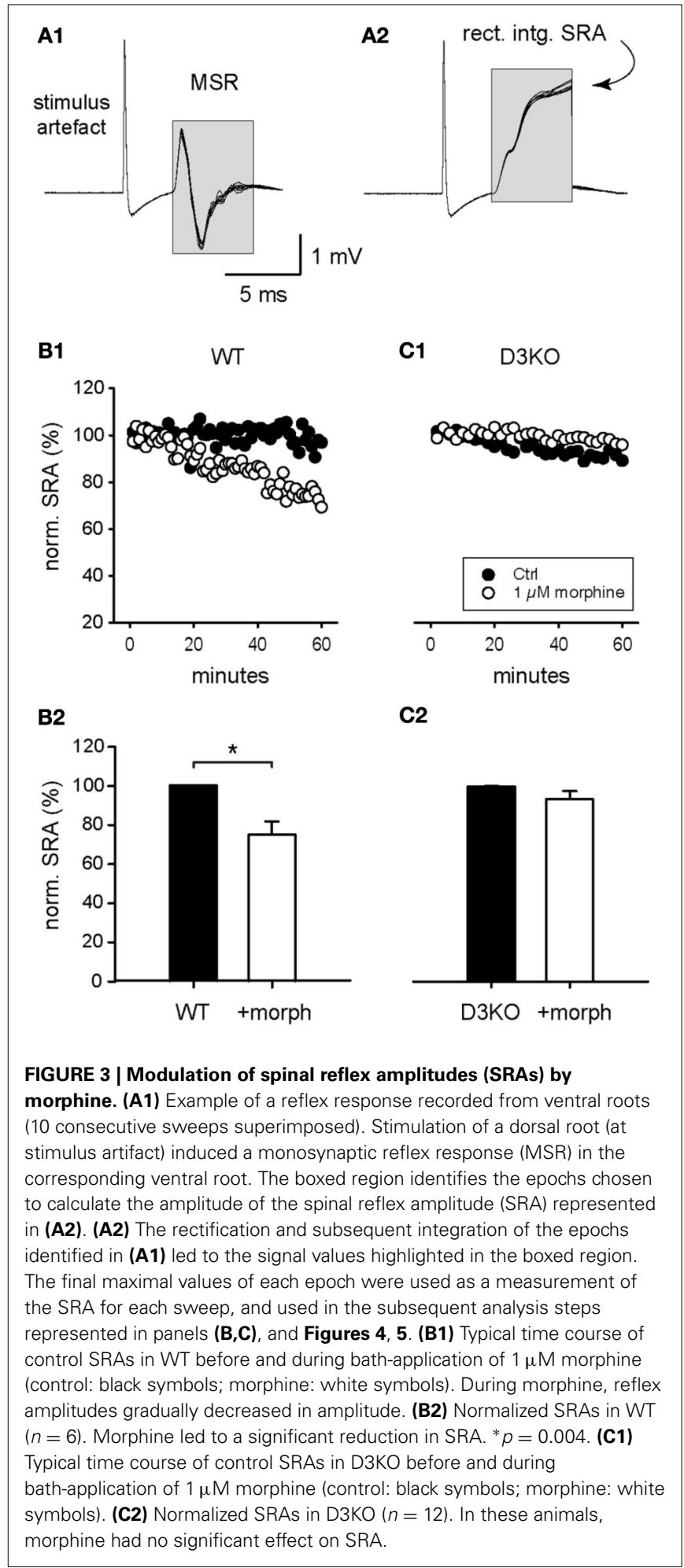

$\mathrm{D} 3 \mathrm{KO}$ both in vivo and in vitro, we tested the consequence of an acute block of the D3 receptor system in the isolated spinal cord prior to morphine exposure (Figure 5). Following baseline recordings, WT spinal cords were exposed to the D3 receptor-preferring antagonist, nafadotride (Figure 5A), before
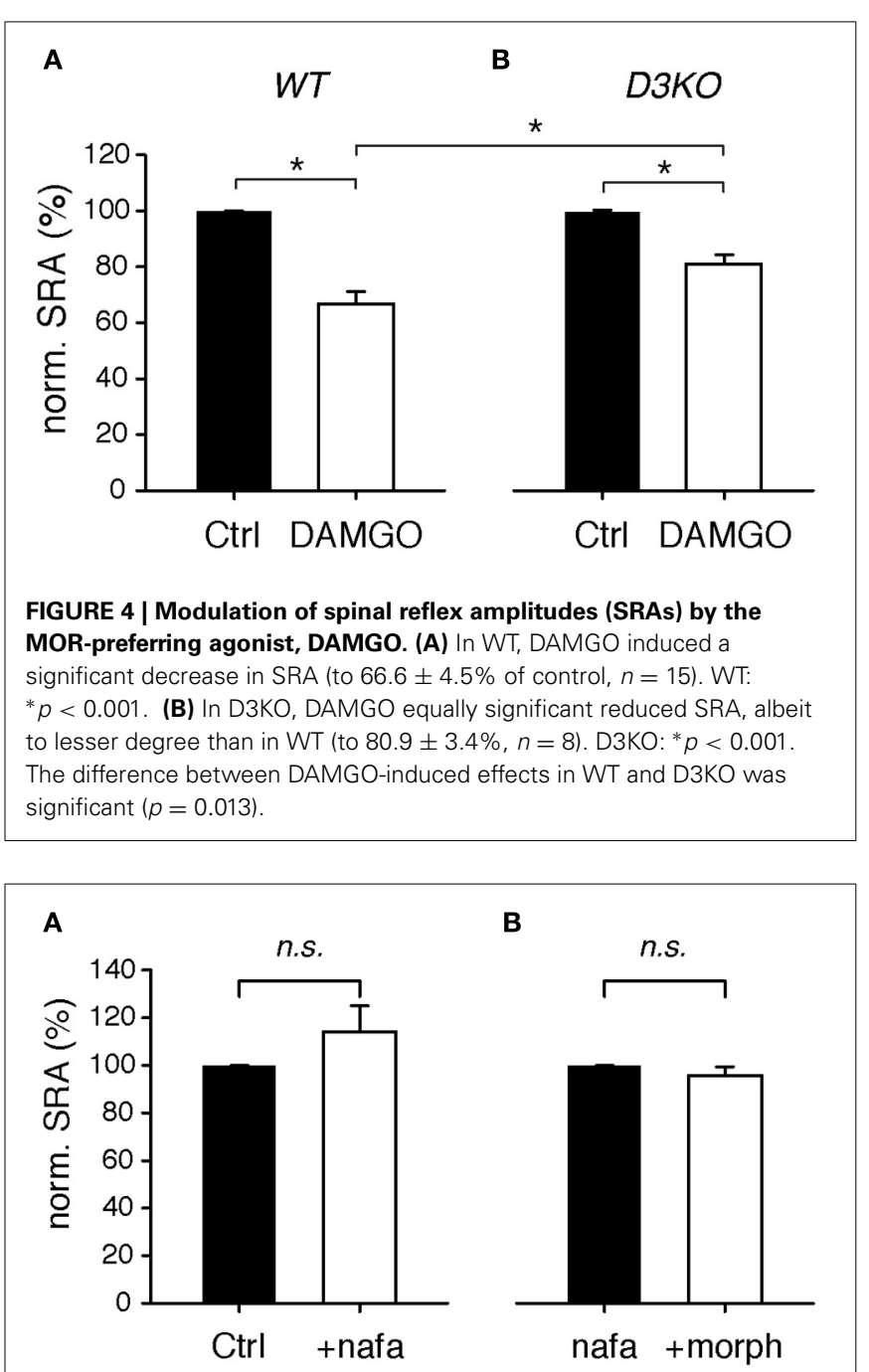

FIGURE 5 | Modulation of spinal reflex amplitudes (SRAs) by the D3-receptor preferring antagonist, nafadotride. (A) In the isolated WT spinal cord, bath-application of nafadotride led to slight, albeit insignificant increase in SRAs $(n=8)$. (B) In the presence of nafadotride, additional application of $1 \mu \mathrm{M}$ morphine failed to exert any modulatory action on SRAs $(n=5)$.

additionally bath-applying morphine (Figure 5B). Application of nafadotride alone $(20 \mu \mathrm{M})$ led to a slight, yet insignificant increase in SRA from $99.7 \pm 0.2$ to $113.9 \pm 11.1 \%(p=0.87$, $n=8$, Figure 5A). Subsequent application of morphine, in the presence of nafadotride, and at the same dose that caused the significant inhibition of SRAs under control conditions (cf. Figure 3) failed to exert any significant modulatory action (ctrl: $99.8 \pm 0.1$ vs. $95.5 \pm 3.9 \%, p=0.69, n=5$, Figure 5B). These data are testimony that an induced acute block of spinal D3 receptors is sufficient to prevent morphine effects.

\section{D1 RECEPTOR EXPRESSION}

As the D3 receptor is closely associated with the D1 receptor through heterodimerization (Surmeier et al., 1996; Fiorentini et al., 2008; Maggio et al., 2009; Missale et al., 2010; Cruz-Trujillo 
et al., 2013), we next tested if the dysfunction of the D3 receptor system leads to changes in the D1 receptor system (Figure 6). We found that in D3KO $(n=5)$, D1 receptor expression $(49 \mathrm{kDa}$ band) increased significantly from $99.99 \pm 4.6 \%$ (in WT) to $170.6 \pm 8.9 \%(n=5, p<0.001)$. These data support the notion that the increased excitability in the D3KO spinal cord could be, at least in part, driven by an increased expression in D1 receptor levels.

\section{DISCUSSION}

We show here that a dysfunction of the dopamine D3 receptor is associated with a morphine-resistant state in vivo, that this behavioral phenotype can be mimicked in the spinal cord in vitro, and that this altered morphine responsiveness is associated with an increase of pMOR but not total MOR expression in the lumbar spinal cord. In addition, we found that an acute block of D3 receptor function in the isolated spinal cord completely abolished the modulatory capabilities of morphine on SRAs, suggesting that the disruption of D3 receptor function in vitro is sufficient to induce a state of morphine resistance.

The D3 receptor is part of the D2-like family, and an evaluation of D1- and D2 receptor agonists, at a time when other DA receptors had not yet been described, reported that D2 activation produced antinociception, whereas D1 receptor activation induced mild hyperalgesia (Rooney and Sewell, 1989). More recently it was shown that co-administration of morphine with nafadotride could effectively suppress the morphine-induced behavioral sensitization observed in WT mice after acute morphine administration (Li et al., 2010), and it was suggested that D3 receptors regulate basal nociception ( $\mathrm{Li}$ et al., 2012). Together, these data support our findings that the D3 receptor may have a critical role in regulating the morphine response in the spinal cord.

Loss of morphine analgesia is generally associated with a reduction in functional MOR receptors, either through downregulation or desensitization of receptors (Williams et al., 2013). Such a down-regulation is characterized by a decrease in functional receptors present on the cell membrane due to degradation or decreased biosynthesis (Finn and Whistler, 2001). We found that D3KO and WT mice had similar levels of total MOR expression indicating that MOR receptor down-regulation per se is not the primary mechanism behind the lack of morphine responsiveness in D3KO mice in vivo (Figure 2). Our studies, however, were insensitive to receptor distribution between cellular compartments which would effect of the availability of functional MOR. Desensitization involves molecular changes at the receptor signaling level (Yu et al., 1997; Bohn et al., 2000), with receptor phosphorylation being the first step. MOR desensitization is under the control of GRK-mediated phosphorylation (Connor et al., 2004; Gainetdinov et al., 2004; Garzon et al., 2005), followed by $ß$-arrestin-mediated internalization (Bohn et al., 1999, 2000; Ohsawa et al., 2003; Connor et al., 2004). Our data show that, while total MOR protein levels were similar across groups, a greater proportion of those receptors were phosphorylated in $\mathrm{D} 3 \mathrm{KO}$ compared to WT, suggesting that these receptors were desensitized and will not effectively signal, even in the presence of a ligand (Figure 2). While the MOR can be phosphorylated by both GPCR kinase (GRK) and non-GRK mechanisms, the antibody used for this experiment was designed to recognize phosphorylation of the Ser375 residue of the MOR, a site that is critical for GRK phosphorylation, arrestin recruitment and endocytosis (El Kouhen et al., 2001). This site has also been shown to be phosphorylated in states of morphine tolerance and with sustained release of $\beta$-endorphin, the endogenous ligand for MOR (Petraschka et al., 2007). Such alterations in binding efficiency of MOR to endogenous opioid ligands may provide one explanation for our findings why $\mathrm{D} 3 \mathrm{KO}$ mice have lower baseline thermal pain thresholds than WT (Keeler et al., 2012), and they may also explain the lack of analgesia with exogenous morphine treatment. Studies assessing GRK activity levels and endogenous opioid levels in D3KO mice are needed to determine if the baseline phosphorylation of the MOR results from either increased GRK activity and/or continuous activation due to an increased availability of endogenous ligand.

A possible limitation of our immunohistochemical findings is that the commercially-generated antibodies used in our study were not, or only to a limited extent, validated in external peer review processes, and thus may not be optimized or only partially effective in detecting the proteins of interest (e.g., the $42 \mathrm{kDa}$ band we observed exclusively in the D3KO spinal cord when probing for the D1 receptor, Figure 6). However, as the $49 \mathrm{kDa}$ band (s. arrows in Figure 6A) corresponds to the predicted D1 receptor protein size, has together with a $75 \mathrm{kDa}$ band also been observed at this size recently (Mizuta et al., 2013), and was both present and differentially expressed in WT and D3KO (Figure 6B), we are confident that future work will corroborate the molecular changes reported in this study. At the same time, given the high structural homology between D1 and D5 receptors, we can not exclude the possibility that such studies may identify an up-regulation of the D5 receptor instead of the D1 receptor as suggested by our findings. Yet, given the similar functional properties of D1 and D5 receptors, both of which primarily mediate excitatory actions, and the lack of evidence of D1/D5 receptor interactions, we have based our model on the existing literature that has identified D1/D3 interaction and heterodimers, which could act in synergistic fashion to control and mediate DA and morphine actions.

Our finding that the MOR agonist DAMGO can induce a modulatory response in both WT and D3KO could be the result of its higher specificity in activating the MOR than morphine (Minami et al., 1995; Onogi et al., 1995; Saidak et al., 2006), which also activate $\partial$-receptors (Walwyn et al., 2009), and/or its high affinity to the MOR (Pak et al., 1996). As we observed lower levels of non$\mathrm{p}-\mathrm{MOR}$ in D3KO than in WT (Figure 2), it is conceivable that DAMGO but not morphine may be able to activate this receptor population in $\mathrm{D} 3 \mathrm{KO}$, thus allowing the modulation of the SRAs in vitro.

Resistance to opioid treatment involves in part the DA system, including the D3 receptor system (Richtand et al., 2001; Sokoloff et al., 2001; Kosten et al., 2002; Vorel et al., 2002; Le Foll et al., 2007; Heidbreder, 2008; Hell, 2009; Li et al., 2012). Such tolerance can arise from a dysfunction of MOR and DA receptor mediated cAMP/PKA second messenger pathways in the brain (Zhao et al., 2007; Barraud et al., 2010). Both DA and MORs are located pre- and post-synaptically in spinal cord sensory 
neurons (Xie et al., 1998; Levant and McCarson, 2001; Abbadie et al., 2002; Millan, 2002) and they control the activation of adenylyl-cyclase (AC). Generally, DA D1-like receptors (D1, D5) mediate excitatory actions by increasing AC activation and raising cAMP levels in the target neuron (Missale et al., 1998; Neve et al., 2004), whereas D2-like (D2, D3, and D4) and MOR pathways reduce AC activation and decrease cAMP levels (Yu et al., 1990; Jaber et al., 1996; Mamiya et al., 2001; Neve et al., 2004; Sheng et al., 2009). As D1 and D3 receptors often co-localize or form heterodimers (Karasinska et al., 2005; Fiorentini et al., 2008, 2010; Marcellino et al., 2008; Beaulieu and Gainetdinov, 2011) and oppositely regulate cAMP/PKA-mediated second messenger pathways, it is conceivable that the dysfunction of the D3 receptor might directly modify D1 receptor function. While we previously did not observe differences in D1 mRNA expression in the D3KO spinal cord (Zhu et al., 2008), probing for the affiliated protein expression revealed a significantly increased D1 receptor protein expression in D3KO (Figure 6), supporting the notion of a D3-mediated influence on D1 function. Additionally, the similarities in MOR- and D3-mediated second messenger pathways suggest that they may have synergistic effects on reducing pain transmission (Li et al., 2012; Saghaei et al., 2012), and the co-localization of D1 with D3 receptors suggest that interactions in their common cAMP/PKA signaling cascade might play a role in the emergence of the morphine resistance seen in $\mathrm{D} 3 \mathrm{KO}$ (Figure 7).

In WT, a nociceptive stimulus induces the release of DA and endogenous opioids, including beta-endorphin, which preferentially bind the D3 and MOR, respectively, and initiate signaling cascades that inhibit cAMP production, resulting in the

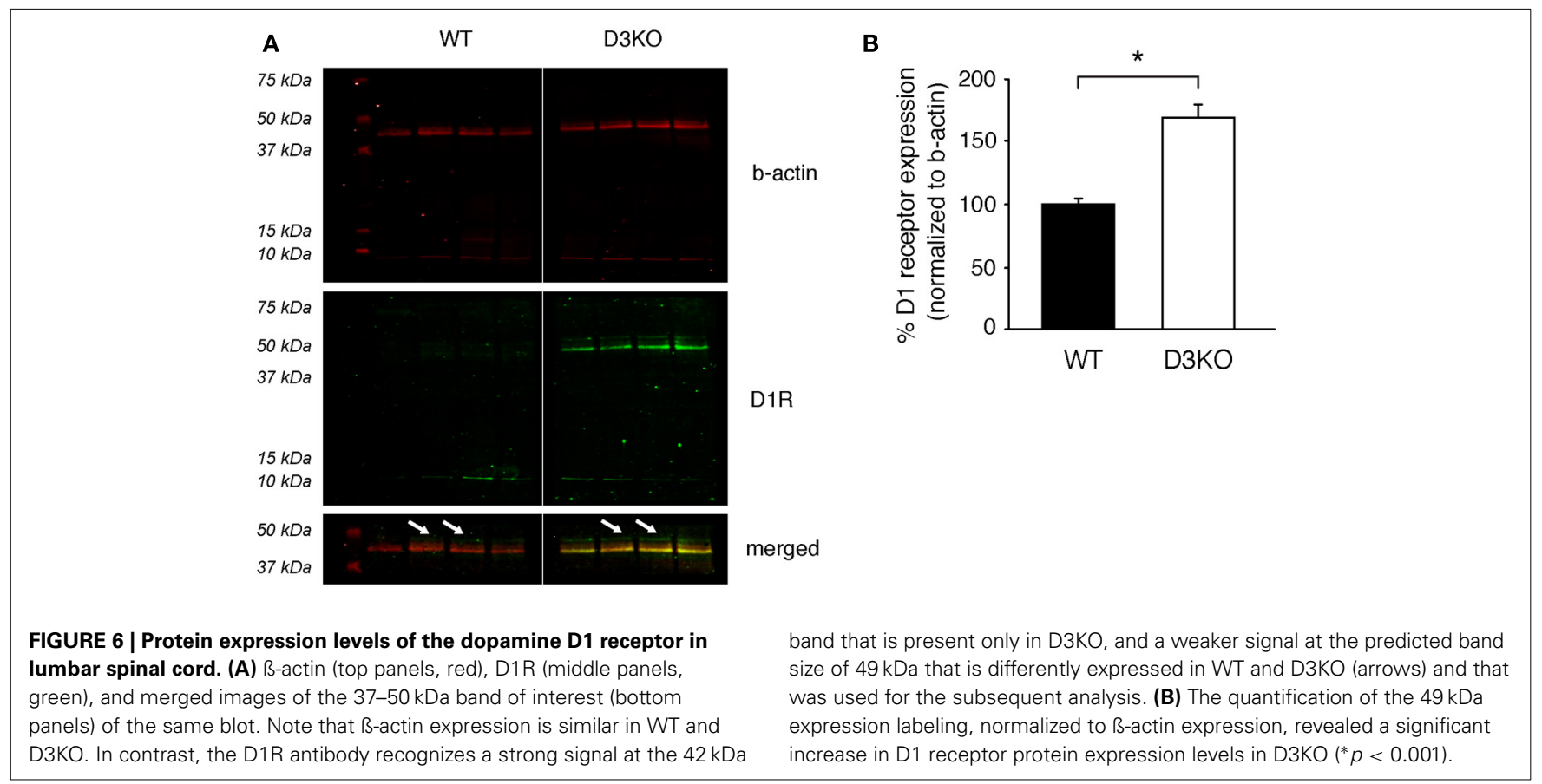
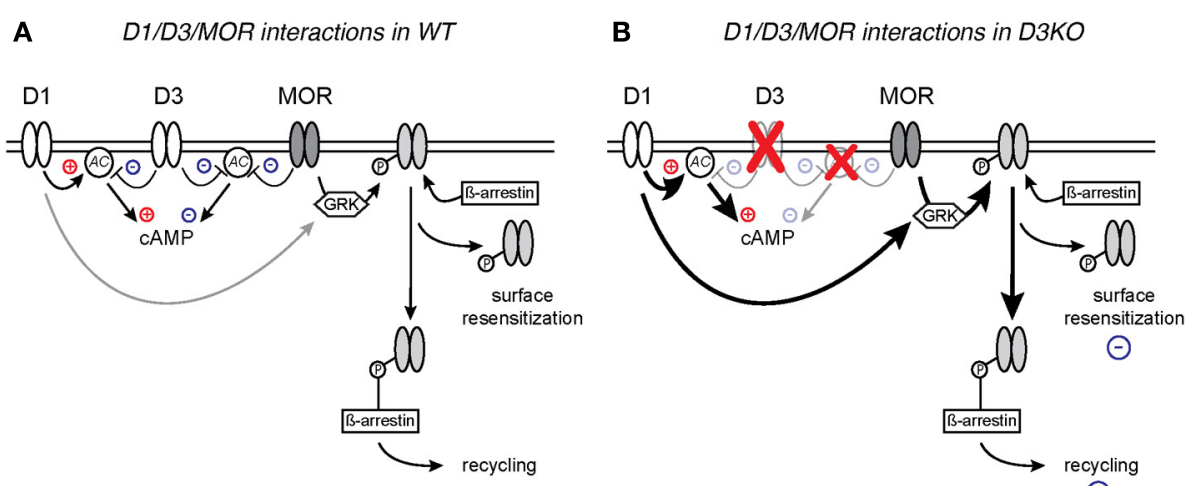

$\odot$

FIGURE 7 | Proposed model of D1 and D3 receptor interactions with MOR in WT (A) and D3KO (B). (A) Naïve WT with intact D1, D3, and MOR signaling pathways. (B) D3KO with compromised D3 function and altered second messenger cascades. 
opening of $\mathrm{K}+$ channels or closing of $\mathrm{Ca}^{2+}$ channels (Connor and Christie, 1999; Connor et al., 1999; Williams et al., 2001) thus decreasing the transmission of the nociceptive signal. MOR binding is followed by GRK-mediated phosphorylation (Connor et al., 2004; Gainetdinov et al., 2004; Garzon et al., 2005), and B-arrestin-mediated internalization (Bohn et al., 1999, 2000; Ohsawa et al., 2003; Connor et al., 2004) of the receptor, followed by recycling or de-phosphorylation and subsequent reinsertion into the membrane. More recent evidence also demonstrates that recovery from phosphorylation and desensitization can occur on the cell membrane, without the need for endocytosis of the receptor (Arttamangkul et al., 2006; Doll et al., 2011).

This intracellular overlap between the MOR and DA systems, along with evidence that D1, but not D2 receptors are involved in mediating the behavioral responses to morphine by acting to recruit GRK and B-arrestin to the MOR (Urs et al., 2011) and that blocking $B$-arrestin expression has been shown to enhance morphine-mediated analgesia (Li et al., 2009), has led to the model proposed in Figure 7. According to our model, activation of the D3 receptor leads in WT to a reduction of adenylate cyclase (AC) activity, which will result in a reduction of cAMP levels and decreased cAMP-mediated signaling, in a manner that is synergistic to the MOR in response to its ligand. However, under this scenario, D1 activation can also activate $\mathrm{AC}$ and compensate for a D3- or MOR-mediated reduction in cAMP levels, thus permitting a bi-directional modulation of cAMP-mediated pathways. As D1 and D3 receptors often co-localize or form heterodimers in the brain (Karasinska et al., 2005; Fiorentini et al., 2008, 2010; Marcellino et al., 2008; Beaulieu and Gainetdinov, 2011) and oppositely regulate cAMP/PKA-mediated second messenger pathways, we postulate that, in D3KO, the dysfunction of the $\mathrm{D} 3$ receptor prevents the D3-mediated block of $\mathrm{AC}$, and leaves D1 receptor actions unopposed. Under such circumstances, cAMP pathways might be continuously up-regulated, and additional application of cAMP nucleotides might fail to further increase cellular excitability. Further, activation of the $D 1$ receptor induces $B$-arrestin signaling complex formation, in which $\beta$-arrestin acts as a scaffold for different kinases and phosphatases (Beaulieu et al., 2005; Urs et al., 2011) which in turn may lead to desensitization of receptors through $G$ proteinindependent signaling mechanisms (Pierce and Lefkowitz, 2001; Lefkowitz and Shenoy, 2005) and increased pMOR levels. We postulate that these changes to the second messenger systems, either individually or in concert, can create the overly excitable cellular state that is evidenced by decreased sensory thresholds at baseline, and the resistance to the analgesic effects of the opiates.

Taken together, our data reinforce the idea that changes in the ability of opioids to provide analgesia can arise from a dysfunctional D3 receptor, as demonstrated using spinally-mediated behaviors and reflex circuits, and that this unresponsiveness to morphine can be induced acutely in the isolated spinal cord by blocking the D3 receptor. Therefore, the D3KO mouse may be a powerful tool with which to study the alterations to the MOR second messenger-signaling cascade, to decipher the initial mechanisms that may underlie the waning of morphine effectiveness over time.

\section{ACKNOWLEDGMENTS}

The authors declare no competing financial interests. We thank Perrine Lallemand for assistance with the immunohistochemical control experiments.

\section{REFERENCES}

Abbadie, C., Lombard, M. C., Besson, J. M., Trafton, J. A., and Basbaum, A. I. (2002). Mu and delta opioid receptor-like immunoreactivity in the cervical spinal cord of the rat after dorsal rhizotomy or neonatal capsaicin: an analysis of pre- and postsynaptic receptor distributions. Brain Res. 930, 150-162. doi: 10.1016/S0006-8993(02)02242-4

Abbadie, C., Pasternak, G. W., and Aicher, S. A. (2001). Presynaptic localization of the carboxy-terminus epitopes of the $\mu$ opioid receptor splice variants MOR-1C and MOR-1D in the superficial laminae of the rat spinal cord. Neuroscience 106, 833-842. doi: 10.1016/S0306-4522(01)00317-7

Arttamangkul, S., Torrecilla, M., Kobayashi, K., Okano, H., and Williams, J. T. (2006). Separation of mu-opioid receptor desensitization and internalization: endogenous receptors in primary neuronal cultures. J. Neurosci. 26, 4118-4125. doi: 10.1523/JNEUROSCI.0303-06.2006

Barraud, Q., Obeid, I., Aubert, I., Barriere, G., Contamin, H., McGuire, S., et al. (2010). Neuroanatomical study of the A11 diencephalospinal pathway in the non-human primate. PLOS ONE 5:e13306. doi: 10.1371/journal.pone.0013306

Beaulieu, J. M., and Gainetdinov, R. R. (2011). The physiology, signaling, and pharmacology of dopamine receptors. Pharmacol. Rev. 63, 182-217. doi: 10.1124/pr.110.002642

Beaulieu, J. M., Sotnikova, T. D., Marion, S., Lefkowitz, R. J., Gainetdinov, R. R., and Caron, M. G. (2005). An Akt/beta-arrestin 2/PP2A signaling complex mediates dopaminergic neurotransmission and behavior. Cell 122, 261-273. doi: 10.1016/j.cell.2005.05.012

Bekhit, M. H. (2010). Opioid-induced hyperalgesia and tolerance. Am. J. Ther. 17, 498-510. doi: 10.1097/MJT.0b013e3181ed83a0

Bohn, L. M., Gainetdinov, R. R., Lin, F. T., Lefkowitz, R. J., and Caron, M. G. (2000). Mu-opioid receptor desensitization by beta-arrestin-2 determines morphine tolerance but not dependence. Nature 408, 720-723. doi: 10.1038/ 35047086

Bohn, L. M., Lefkowitz, R. J., Gainetdinov, R. R., Peppel, K., Caron, M. G., and Lin, F. T. (1999). Enhanced morphine analgesia in mice lacking beta-arrestin 2. Science 286, 2495-2498. doi: 10.1126/science.286.5449.2495

Clemens, S., and Hochman, S. (2004). Conversion of the modulatory actions of dopamine on spinal reflexes from depression to facilitation in D3 receptor knock-out mice. J. Neurosci. 24, 11337-11345. doi: 10.1523/JNEUROSCI.369804.2004

Colpaert, F. C. (2002). Mechanisms of opioid-induced pain and antinociceptive tolerance: signal transduction. Pain 95, 287-288. doi: 10.1016/S03043959(01)00445-6

Connor, M., and Christie, M. D. (1999). Opioid receptor signalling mechanisms. Clin. Exp. Pharmacol. Physiol. 26, 493-499. doi: 10.1046/j.14401681.1999.03049.x

Connor, M., Osborne, P. B., and Christie, M. J. (2004). Mu-opioid receptor desensitization: is morphine different? Br. J. Pharmacol. 143, 685-696. doi: 10.1038/sj.bjp.0705938

Connor, M., Schuller, A., Pintar, J. E., and Christie, M. J. (1999). Mu-opioid receptor modulation of calcium channel current in periaqueductal grey neurons from C57B16/J mice and mutant mice lacking MOR-1. Br. J. Pharmacol. 126, 1553-1558. doi: 10.1038/sj.bjp.0702457

Cook, C. D., Barrett, A. C., Syvanthong, C., and Picker, M. J. (2000). Modulatory effects of dopamine D3/2 agonists on kappa opioid-induced antinociception and diuresis in the rat. Psychopharmacology (Berl.) 152, 14-23. doi: $10.1007 / \mathrm{s} 002130000519$

Cruz-Trujillo, R., Avalos-Fuentes, A., Rangel-Barajas, C., Paz-Bermudez, F., Sierra, A., Escartin-Perez, E., et al. (2013). D3 dopamine receptors interact with dopamine D1 but not D4 receptors in the GABAergic terminals of the $\mathrm{SNr}$ of the rat. Neuropharmacology 67, 370-378. doi: 10.1016/j.neuropharm.2012. 11.032

Doll, C., Konietzko, J., Poll, F., Koch, T., Hollt, V., and Schulz, S. (2011). Agonist-selective patterns of micro-opioid receptor phosphorylation revealed by phosphosite-specific antibodies. Br. J. Pharmacol. 164, 298-307. doi: 10.1111/j.1476-5381.2011.01382.x 
Dupen, A., Shen, D., and Ersek, M. (2007). Mechanisms of opioidinduced tolerance and hyperalgesia. Pain Manag. Nurs. 8, 113-121. doi: 10.1016/j.pmn.2007.02.004

El Kouhen, R., Burd, A. L., Erickson-Herbrandson, L. J., Chang, C. Y., Law, P. Y., and Loh, H. H. (2001). Phosphorylation of Ser363, Thr370, and Ser375 residues within the carboxyl tail differentially regulates mu-opioid receptor internalization. J. Biol. Chem. 276, 12774-12780. doi: 10.1074/jbc.M009571200

Enoksson, T., Bertran-Gonzalez, J., and Christie, M. J. (2012). Nucleus accumbens D2- and D1-receptor expressing medium spiny neurons are selectively activated by morphine withdrawal and acute morphine, respectively. Neuropharmacology 62, 2463-2471. doi: 10.1016/j.neuropharm.2012.02.020

Fazli-Tabaei, S., Yahyavi, S. H., Nouri, M., Zartab, H., Javid, G., Loghavi, S., et al. (2006). Dopamine receptor mechanism(s) and antinociception and tolerance induced by swim stress in formalin test. Behav. Pharmacol. 17, 341-347. doi: 10.1097/01.fbp.0000224383.63744.69

Finn, A. K., and Whistler, J. L. (2001). Endocytosis of the mu opioid receptor reduces tolerance and a cellular hallmark of opiate withdrawal. Neuron 32, 829-839. doi: 10.1016/S0896-6273(01)00517-7

Fiorentini, C., Busi, C., Gorruso, E., Gotti, C., Spano, P., and Missale, C. (2008). Reciprocal regulation of dopamine D1 and D3 receptor function and trafficking by heterodimerization. Mol. Pharmacol. 74, 59-69. doi: 10.1124/mol.107.043885

Fiorentini, C., Busi, C., Spano, P., and Missale, C. (2010). Dimerization of dopamine D1 and D3 receptors in the regulation of striatal function. Curr. Opin. Pharmacol. 10, 87-92. doi: 10.1016/j.coph.2009.09.008

Gainetdinov, R. R., Premont, R. T., Bohn, L. M., Lefkowitz, R. J., and Caron, M. G. (2004). Desensitization of G protein-coupled receptors and neuronal functions. Annu. Rev. Neurosci. 27, 107-144. doi: 10.1146/annurev.neuro.27.070203.144206

Garraway, S. M., and Hochman, S. (2001). Modulatory actions of serotonin, norepinephrine, dopamine, and acetylcholine in spinal cord deep dorsal horn neurons. J. Neurophysiol. 86, 2183-2194.

Garzon, J., Rodriguez-Munoz, M., and Sanchez-Blazquez, P. (2005). Morphine alters the selective association between mu-opioid receptors and specific RGS proteins in mouse periaqueductal gray matter. Neuropharmacology 48, 853-868. doi: 10.1016/j.neuropharm.2005.01.004

Heidbreder, C. (2008). Selective antagonism at dopamine D3 receptors as a target for drug addiction pharmacotherapy: a review of preclinical evidence. CNS Neurol. Disord. Drug Targets 7, 410-421. doi: 10.2174/187152708786 927822

Hell, J. W. (2009). Hooked on the D3 receptor: CaMKII's new addiction. Neuron 61, 335-336. doi: 10.1016/j.neuron.2009.01.025

Jaber, M., Robinson, S. W., Missale, C., and Caron, M. G. (1996). Dopamine receptors and brain function. Neuropharmacology 35, 1503-1519. doi: 10.1016/S0028-3908(96)00100-1

Ji, R. R., Zhang, Q., Law, P.-Y., Low, H. H., Elde, R., and Hökfelt, T. (1995). Expression of $\mu-, \delta$, and $\kappa$-opioid receptor-like immunoreactivities in rat dorsal root ganglia after carrageenan-induced inflammation. J. Neurosci. 15, 8156-8166.

Joseph, E. K., Reichling, D. B., and Levine, J. D. (2010). Shared mechanisms for opioid tolerance and a transition to chronic pain. J. Neurosci. 30, 4660-4666. doi: 10.1523/JNEUROSCI.5530-09.2010

Karasinska, J. M., George, S. R., Cheng, R., and O'Dowd, B. F. (2005). Deletion of dopamine D1 and D3 receptors differentially affects spontaneous behaviour and cocaine-induced locomotor activity, reward and CREB phosphorylation. Eur. J. Neurosci. 22, 1741-1750. doi: 10.1111/j.1460-9568.2005.04353.x

Keeler, B. E., Baran, C. A., Brewer, K. L., and Clemens, S. (2012). Increased excitability of spinal pain reflexes and altered frequency-dependent modulation in the dopamine D3-receptor knockout mouse. Exp. Neurol. 238, 273-283. doi: 10.1016/j.expneurol.2012.09.002

Kerros, C., Brood, I., Sola, B., Jauzac, P., and Allouche, S. (2010). Reduction of cell proliferation and potentiation of Fas-induced apoptosis by the selective kappa-opioid receptor agonist U50 488 in the multiple myeloma LP-1 cells. J. Neuroimmunol. 220, 69-78. doi: 10.1016/j.jneuroim.2010.01.010

Kosten, T. R., George, T. P., and Kosten, T. A. (2002). The potential of dopamine agonists in drug addiction. Expert Opin. Investig. Drugs 11, 491-499. doi: 10.1517/13543784.11.4.491

Lefkowitz, R. J., and Shenoy, S. K. (2005). Transduction of receptor signals by betaarrestins. Science 308, 512-517. doi: 10.1126/science.1109237
Le Foll, B., Goldberg, S. R., and Sokoloff, P. (2007). Dopamine D3 receptor ligands for the treatment of tobacco dependence. Expert Opin. Investig. Drugs 16, 45-57. doi: 10.1517/13543784.16.1.45

Le Marec, T., Marie-Claire, C., Noble, F., and Marie, N. (2011). Chronic and intermittent morphine treatment differently regulates opioid and dopamine systems: a role in locomotor sensitization. Psychopharmacology (Berl.) 216, 297-303. doi: 10.1007/s00213-011-2223-6

Levant, B., and McCarson, K. E. (2001). D(3) dopamine receptors in rat spinal cord: implications for sensory and motor function. Neurosci. Lett. 303, 9-12. doi: 10.1016/S0304-3940(01)01692-5

Li, T., Hou, Y., Cao, W., Yan, C. X., Chen, T., and Li, S. B. (2012). Role of dopamine D3 receptors in basal nociception regulation and in morphine-induced tolerance and withdrawal. Brain Res. 1433, 80-84. doi: 10.1016/j.brainres.2011.11.045

Li, T., Hou, Y., Yan, C. X., Chen, T., Zhao, Y., and Li, S. B. (2010). Dopamine D3 receptor knock-out mice display deficits in locomotor sensitization after chronic morphine administration. Neurosci. Lett. 485, 256-260. doi: 10.1016/j.neulet.2010.09.025

Li, Y., Liu, X., Liu, C., Kang, J., Yang, J., Pei, G., et al. (2009). Improvement of morphine-mediated analgesia by inhibition of beta-arrestin 2 expression in mice periaqueductal gray matter. Int. J. Mol. Sci. 10, 954-963. doi: 10.3390/ijms10030954

Lin, C. W., Bianchi, B. R., Miller, T. R., Stashko, M. A., Wang, S. S., Curzon, P., et al. (1996). Persistent activation of the dopamine D1 receptor contributes to prolonged receptor desensitization: studies with A-77636. J. Pharmacol. Exp. Ther. 276, 1022-1029.

Loyd, D. R., Wang, X., and Murphy, A. Z. (2008). Sex differences in micro-opioid receptor expression in the rat midbrain periaqueductal gray are essential for eliciting sex differences in morphine analgesia. J. Neurosci. 28, 14007-14017. doi: 10.1523/JNEUROSCI.4123-08.2008

Maggio, R., Aloisi, G., Silvano, E., Rossi, M., and Millan, M. J. (2009) Heterodimerization of dopamine receptors: new insights into functional and therapeutic significance. Parkinsonism Relat. Disord. 15(Suppl. 4), S2-S7. doi: 10.1016/S1353-8020(09)70826-0

Mamiya, T., Noda, Y., Ren, X., Hamdy, M., Furukawa, S., Kameyama, T., et al. (2001). Involvement of cyclic AMP systems in morphine physical dependence in mice: prevention of development of morphine dependence by rolipram, a phosphodiesterase 4 inhibitor. Br. J. Pharmacol. 132, 1111-1117. doi: 10.1038/sj.bjp.0703912

Mansour, A., Fox, C. A., Burke, S., Meng, F., Thompson, R. C., Akil, H., et al. (1994). Mu, delta, and kappa opioid receptor mRNA expression in the rat CNS: an in situ hybridization study. J. Comp. Neurol. 350, 412-438. doi: 10.1002/cne.903500307

Marcellino, D., Ferre, S., Casado, V., Cortes, A., Le Foll, B., Mazzola, C., et al. (2008). Identification of dopamine D1-D3 receptor heteromers. Indications for a role of synergistic D1-D3 receptor interactions in the striatum. J. Biol. Chem. 283, 26016-26025. doi: 10.1074/jbc.M710349200

Millan, M. J. (2002). Descending control of pain. Prog. Neurobiol. 66, 355-474. doi: 10.1016/S0301-0082(02)00009-6

Minami, M., Onogi, T., Nakagawa, T., Katao, Y., Aoki, Y., Katsumata, S., et al. (1995). DAMGO, a mu-opioid receptor selective ligand, distinguishes between mu-and kappa-opioid receptors at a different region from that for the distinction between mu- and delta-opioid receptors. FEBS Lett. 364, 23-27. doi: 10.1016/0014-5793(95)00340-F

Missale, C., Fiorentini, C., Collo, G., and Spano, P. (2010). The neurobiology of dopamine receptors: evolution from the dual concept to heterodimer complexes. J. Recept. Signal Transduct. Res. 30, 347-354. doi: $10.3109 / 10799893.2010 .506192$

Missale, C., Nash, S. R., Robinson, S. W., Jaber, M., and Caron, M. G. (1998). Dopamine receptors: from structure to function. Physiol. Rev. 78, 189-225.

Mizuta, K., Zhang, Y., Xu, D., Mizuta, F., D’Ovidio, F., Masaki, E., et al. (2013). The dopamine D1 receptor is expressed and facilitates relaxation in airway smooth muscle. Respir. Res. 14, 89. doi: 10.1186/1465-9921-14-89

Neve, K. A., Seamans, J. K., and Trantham-Davidson, H. (2004). Dopamine receptor signaling. J. Recept. Signal Transduct. Res. 24, 165-205. doi: 10.1081/RRS200029981

Ohsawa, M., Mizoguchi, H., Narita, M., Nagase, H., Dun, N. J., and Tseng, L. F. (2003). Involvement of beta-arrestin-2 in modulation of the spinal 
antinociception induced by mu-opioid receptor agonists in the mouse. Neurosci. Lett. 346, 13-16. doi: 10.1016/S0304-3940(03)00591-3

Onogi, T., Minami, M., Katao, Y., Nakagawa, T., Aoki, Y., Toya, T., et al. (1995). DAMGO, a mu-opioid receptor selective agonist, distinguishes between muand delta-opioid receptors around their first extracellular loops. FEBS Lett. 357, 93-97. doi: 10.1016/0014-5793(94)01341-W

Pak, Y., Kouvelas, A., Scheideler, M. A., Rasmussen, J., O’Dowd, B. F., and George, S. R. (1996). Agonist-induced functional desensitization of the mu-opioid receptor is mediated by loss of membrane receptors rather than uncoupling from $\mathrm{G}$ protein. Mol. Pharmacol. 50, 1214-1222.

Petraschka, M., Li, S., Gilbert, T. L., Westenbroek, R. E., Bruchas, M. R., Schreiber, S., et al. (2007). The absence of endogenous beta-endorphin selectively blocks phosphorylation and desensitization of mu opioid receptors following partial sciatic nerve ligation. Neuroscience 146, 1795-1807. doi: 10.1016/j.neuroscience.2007.03.029

Pierce, K. L., and Lefkowitz, R. J. (2001). Classical and new roles of beta-arrestins in the regulation of G-protein-coupled receptors. Nat. Rev. Neurosci. 2, 727-733. doi: $10.1038 / 35094577$

Ray, S. B., and Wadhwa, S. (1999). Mu opioid receptors in developing human spinal cord. J. Anat. 195(Pt 1), 11-18. doi: 10.1046/j.1469-7580.1999. 19510011.x

Ray, S. B., and Wadhwa, S. (2004). Expression of mu-opioid receptors in developing rat spinal cord: an autoradiographic study. Indian J. Exp. Biol. 42, 533-537.

Richtand, N. M., Goldsmith, R. J., Nolan, J. E., and Berger, S. P. (2001). The D3 dopamine receptor and substance dependence. J. Addict. Dis. 20, 19-32. doi: 10.1300/J069v20n03_03

Richtand, N. M., Logue, A. D., Welge, J. A., Perdiue, J., Tubbs, L. J., Spitzer, R. H., et al. (2000). The dopamine D3 receptor antagonist nafadotride inhibits development of locomotor sensitization to amphetamine. Brain Res. 867, 239-242. doi: 10.1016/S0006-8993(00)02247-2

Rooney, K. F., and Sewell, R. D. (1989). Evaluation of selective actions of dopamine D-1 and D-2 receptor agonists and antagonists on opioid antinociception. Eur. J. Pharmacol. 168, 329-336. doi: 10.1016/0014-2999(89)90794-2

Saghaei, E., Moini Zanjani, T., Sabetkasaei, M., and Naseri, K. (2012). Enhancement of antinociception by co-administrations of nefopam, morphine, and nimesulide in a rat model of neuropathic pain. Korean J. Pain 25, 7-15. doi: 10.3344/kjp.2012.25.1.7

Saidak, Z., Blake-Palmer, K., Hay, D. L., Northup, J. K., and Glass, M. (2006). Differential activation of G-proteins by mu-opioid receptor agonists. $\mathrm{Br} . \mathrm{J}$. Pharmacol. 147, 671-680. doi: 10.1038/sj.bjp.0706661

Schmidt, B. L., Tambeli, C. H., Barletta, J., Luo, L., Green, P., Levine, J. D., et al. (2002). Altered nucleus accumbens circuitry mediates pain-induced antinociception in morphine-tolerant rats. J. Neurosci. 22, 6773-6780.

Sheng, H. Y., Qu, C. L., Huo, F. Q., Du, J. Q., and Tang, J. S. (2009). D2-like but not D1-like dopamine receptors are involved in the ventrolateral orbital cortexinduced antinociception: a GABAergic modulation mechanism. Exp. Neurol. 215, 128-134. doi: 10.1016/j.expneurol.2008.09.018

Sokoloff, P., Le Foll, B., Perachon, S., Bordet, R., Ridray, S., and Schwartz, J. C. (2001). The dopamine D3 receptor and drug addiction. Neurotox. Res. 3, 433-441. doi: 10.1007/BF03033202

Surmeier, D. J., Song, W. J., and Yan, Z. (1996). Coordinated expression of dopamine receptors in neostriatal medium spiny neurons. J. Neurosci. 16, 6579-6591.

Suzuki, T., Kishimoto, Y., Ozaki, S., and Narita, M. (2001). Mechanism of opioid dependence and interaction between opioid receptors. Eur. J. Pain 5(Suppl. A), 63-65. doi: 10.1053/eujp.2001.0282

Urs, N. M., Daigle, T. L., and Caron, M. G. (2011). A dopamine D1 receptor-dependent beta-arrestin signaling complex potentially regulates morphine-induced psychomotor activation but not reward in mice. Neuropsychopharmacology 36, 551-558. doi: 10.1038/npp.2010.186

Vorel, S. R., Ashby, C. R. Jr., Paul, M., Liu, X., Hayes, R., Hagan, J. J., et al. (2002). Dopamine D3 receptor antagonism inhibits cocaine-seeking and cocaineenhanced brain reward in rats. J. Neurosci. 22, 9595-9603.
Walwyn, W., John, S., Maga, M., Evans, C. J., and Hales, T. G. (2009). Delta receptors are required for full inhibitory coupling of mu-receptors to voltagedependent $\mathrm{Ca}(2+)$ channels in dorsal root ganglion neurons. Mol. Pharmacol. 76, 134-143. doi: 10.1124/mol.109.055913

Williams, J. T., Christie, M. J., and Manzoni, O. (2001). Cellular and synaptic adaptations mediating opioid dependence. Physiol. Rev. 81, 299-343.

Williams, J. T., Ingram, S. L., Henderson, G., Chavkin, C., Von Zastrow, M., Schulz, S., et al. (2013). Regulation of mu-opioid receptors: desensitization, phosphorylation, internalization, and tolerance. Pharmacol. Rev. 65, 223-254. doi: 10.1124/pr.112.005942

Xie, G. X., Jones, K., Peroutka, S. J., and Palmer, P. P. (1998). Detection of mRNAs and alternatively spliced transcripts of dopamine receptors in rat peripheral sensory and sympathetic ganglia. Brain Res. 785, 129-135. doi: 10.1016/S00068993(97)01394-2

Yang, H. W., Zhou, L. J., Hu, N. W., Xin, W. J., and Liu, X. G. (2005). Activation of spinal $\mathrm{d} 1 / \mathrm{d} 5$ receptors induces late-phase LTP of C-fiber-evoked field potentials in rat spinal dorsal horn. J. Neurophysiol. 94, 961-967. doi: 10.1152/jn.01324.2004

Yu, V. C., Eiger, S., Duan, D. S., Lameh, J., and Sadee, W. (1990). Regulation of cyclic AMP by the mu-opioid receptor in human neuroblastoma SH-SY5Y cells. J. Neurochem. 55, 1390-1396. doi: 10.1111/j.1471-4159.1990.tb03151.x

Yu, Y., Zhang, L., Yin, X., Sun, H., Uhl, G. R., and Wang, J. B. (1997). Mu opioid receptor phosphorylation, desensitization, and ligand efficacy. J. Biol. Chem. 272, 28869-28874. doi: 10.1074/jbc.272.46.28869

Zhang, D., Zhang, H., Jin, G. Z., Zhang, K., and Zhen, X. (2008). Single dose of morphine produced a prolonged effect on dopamine neuron activities. Mol. Pain 4, 57.

Zhang, Y., Pan, Y. X., Kolesnikov, Y., and Pasternak, G. W. (2006). Immunohistochemical labeling of the mu opioid receptor carboxy terminal splice variant mMOR-1B4 in the mouse central nervous system. Brain Res. 1099, 33-43. doi: 10.1016/j.brainres.2006.04.133

Zhang, Y., Zhang, F., Yang, C., Jin, H., Yang, Y., and Xu, M. (2012). Dopamine affects the change of pain-related electrical activity induced by morphine dependence. Neurochem. Res. 37, 977-982. doi: 10.1007/s11064-011-0690-0

Zhao, H., Zhu, W., Pan, T., Xie, W., Zhang, A., Ondo, W. G., et al. (2007). Spinal cord dopamine receptor expression and function in mice with 6-OHDA lesion of the A11 nucleus and dietary iron deprivation. J. Neurosci. Res. 85, 1065-1076. doi: 10.1002/jnr.21207

Zhu, H., Clemens, S., Sawchuk, M., and Hochman, S. (2007). Expression and distribution of all dopamine receptor subtypes $(D(1)-D(5))$ in the mouse lumbar spinal cord: a real-time polymerase chain reaction and nonautoradiographic in situ hybridization study. Neuroscience 149, 885-897. doi: 10.1016/j.neuroscience.2007.07.052

Zhu, H., Clemens, S., Sawchuk, M., and Hochman, S. (2008). Unaltered D1, D2, D4, and D5 dopamine receptor mRNA expression and distribution in the spinal cord of the D3 receptor knockout mouse. J. Comp. Physiol. A Neuroethol. Sens. Neural Behav. Physiol. 194, 957-962. doi: 10.1007/s00359-008-0368-5

Conflict of Interest Statement: The authors declare that the research was conducted in the absence of any commercial or financial relationships that could be construed as a potential conflict of interest.

Received: 10 March 2014; accepted: 23 May 2014; published online: 11 June 2014. Citation: Brewer KL, Baran CA, Whitfield BR, Jensen AM and Clemens S (2014) Dopamine D3 receptor dysfunction prevents anti-nociceptive effects of morphine in the spinal cord. Front. Neural Circuits 8:62. doi: 10.3389/fncir.2014.00062

This article was submitted to the journal Frontiers in Neural Circuits.

Copyright (c) 2014 Brewer, Baran, Whitfield, Jensen and Clemens. This is an openaccess article distributed under the terms of the Creative Commons Attribution License (CC BY). The use, distribution or reproduction in other forums is permitted, provided the original author(s) or licensor are credited and that the original publication in this journal is cited, in accordance with accepted academic practice. No use, distribution or reproduction is permitted which does not comply with these terms. 